\title{
Cyclic GMP-dependent inhibition of acid sphingomyelinase by nitric oxide: an early step in protection against apoptosis
}

\author{
R Barsacchi ${ }^{1}$, C Perrotta ${ }^{1,4}$, P Sestili ${ }^{2}$, O Cantoni ${ }^{2}$, \\ $S$ Moncada ${ }^{3}$ and $E$ Clementi ${ }^{\star}, 1,4$ \\ 1 Department of Neuroscience-DIBIT H San Raffaele Institute, Vita-Salute \\ University, 20132 Milano, Italy \\ 2 Institute of Pharmacology, University of Urbino, 61029 Urbino, Italy \\ ${ }^{3}$ The Wolfson Institute for Biomedical Research, University College London, \\ London WC1E 6BT, UK \\ ${ }^{4}$ Department of Pharmaco-Biology, University of Calabria, 87036 Rende, Italy \\ * Corresponding author: E Clementi, DIBIT-H San Raffaele Institute, via \\ Olgettina 58, 20129 Milano, Italy. Tel: +39 022643 4807; \\ Fax: +39 022643 4813; E-mail: clementi.emilio@hsr.it
}

Received 19.2.02; revised 17.6.02; accepted 19.6 .02

Edited by G Melino

\begin{abstract}
Activation of acid and neutral sphingomyelinases, and the ensuing generation of ceramide, contributes to the biological effects of tumour necrosis factor- $\alpha$ (TNF- $\alpha$ ), one of which is apoptosis. While the mechanisms of activation of sphingomyelinases by the cytokine are being unravelled, less is known about regulation of their activity. Nitric oxide has previously been shown to exert a cyclic GMP-dependent inhibition of early apoptotic events triggered by TNF- $\alpha$ in the U937 monocytic cell line. We therefore investigated whether inhibition of sphingomyelinases by nitric oxide plays a role in regulating such early events. We found that activation of both acid and neutral sphingomyelinases, triggered in the first minutes after U937 cell stimulation with TNF- $\alpha$, is regulated in an inhibitory fashion by nitric oxide, working through generation of cyclic GMP and activation of protein kinase G. Using a range of inhibitors selective for either sphingomyelinase we found that the acid sphingomyelinase contributes to activation of the initiator caspase-8 and early DNA fragmentation and that inhibition of the acid enzyme by nitric oxide accounts for cyclic GMP-dependent early protection from apoptosis. We also found that the protective effect by both cGMP and acid sphingomyelinase inhibitors progressively disappeared at later stages of the apoptotic process. Inhibition of sphingomyelinases represents a novel action of nitric oxide, which might be of physiological relevance in regulating initial phases of apoptosis as well as other biological actions of ceramide.
\end{abstract}

Cell Death and Differentiation (2002) 9, 1248-1255. doi:10.1038/sj.cdd.4401095

Keywords: nitric oxide; cyclic GMP; apoptosis; tumour necrosis factor- $\alpha$; sphingomyelinases
Abbreviations: NO, nitric oxide; TNF- $\alpha$ and TNF-RI, tumour necrosis factor- $\alpha$ and its $p 55 \mathrm{kD}$ a receptor; A-SMase and N-SMase, acid and neutral sphingomyelinases; cGMP, cyclic GMP; SNAP, S-nitroso-acetylpenicillamine; ODQ, $\mathrm{H}-[1,2,4]$ oxadiazolo[4,3- $\alpha]-$ quinoxalin-1-one; D609, tricyclodecan-9-yl xanthate; CHX, cycloheximide

\section{Introduction}

Cell death via apoptosis is a biological process triggered by several stimuli, among which are activation of death receptors, e.g. CD95 and the p55 kDa receptor for tumour necrosis factor- $\alpha$ (TNF-R1), nutrient deprivation, as well as exposure to irradiation and chemotherapeutic agents. ${ }^{1}$ Intracellular pathways triggered by these stimuli include activation of the caspase family of cysteine proteases and mitochondria-associated processes that open the way to the cascade of signalling events leading to cell death. ${ }^{1}$

Apoptosis plays a fundamental role in the development of multicellular organisms and the maintenance of tissue homeostasis. As a consequence of this, the signalling pathways responsible for its initiation and progress are tightly regulated at various levels by proteins and messenger molecules. ${ }^{2}$ Among the latter, a relevant role is played by nitric oxide (NO), which protects from apoptosis induced by a variety of stimuli. Many of the mechanisms through which NO inhibits apoptosis appear to be independent of its ability to activate guanylate cyclase and generate cyclic GMP (cGMP). ${ }^{3}$ Nevertheless, in some cell systems the anti-apoptotic function of $\mathrm{NO}$ is mediated by this cyclic nucleotide. ${ }^{3}$ There is some evidence to suggest that cGMP acts by inhibiting downstream events, namely cytochrome $c$ release and opening of the mitochondrial permeability transition pore, ${ }^{3,4}$ and/or overexpression of Bax and of the $\mathrm{Bcl}-2$ binding protein BNIP3. $^{3,5}$ In the case of apoptosis triggered by tumour necrosis factor- $\alpha$ (TNF- $\alpha$ ), however, cGMP-dependent protection by $\mathrm{NO}$ appears also to involve inhibition of initial events in the apoptotic cascade, i.e. recruitment to TNF-RI of the DISC protein TRADD and ensuing activation of the initiator caspase-8. ${ }^{6}$ This effect of NO/cGMP is due to impairment of the TNF- $\alpha$-triggered generation of the proapoptotic lipid messenger ceramide and occurs in the first minutes after cytokine addition to the cells. ${ }^{6}$ This observation implies that cGMP-dependent inhibition of ceramide generation may function to inhibit apoptosis at its very onset.

Ceramide contributes to apoptosis triggered not only by TNF- $\alpha$, but also by a variety of stimuli. ${ }^{7-9}$ For example, inhibition of ceramide formation by NO/cGMP protects $T$ lymphocytes from apoptosis induced by CD95 and by microbial antigens. ${ }^{10,11}$ Characterisation of the mechanisms by which NO/cGMP inhibits the early wave of ceramide 
generation might, therefore, define the role of $\mathrm{NO}$ in controlling the initiation of apoptosis by a variety of agents.

We have therefore investigated the mechanisms through which NO inhibits early generation of ceramide triggered by TNF- $\alpha$. For this purpose we used the U937 pro-monocytic cell line, which provides a model for TNF- $\alpha /$ ceramide signalling in apoptosis devoid of any intrinsic NO synthase activity. ${ }^{6,12}$ Among the various enzymes regulating the cellular concentration of ceramide we have focused on acid and neutral sphingomyelinases (A-SMase and N-SMase) since they are activated by TNF- $\alpha$ early enough to account for the initial wave of ceramide generation. ${ }^{7-9}$ Our results show that exogenously administered NO, through generation of cGMP and activation of protein kinase $G$, inhibits both enzymatic activities, and that inhibition of A-SMase accounts for the early, cGMP-dependent protection from TNF- $\alpha$-induced apoptosis.

\section{Results}

To study the role of $\mathrm{NO}$ in regulating SMases, the kinetics of activation by TNF- $\alpha$ of both A-SMase and N-SMase were analyzed. U937 cells were treated with TNF- $\alpha(50 \mathrm{ng} / \mathrm{ml})$ and SMase activity measured in cell lysates at the optimum $\mathrm{pH}$ for

$\mathbf{A}$

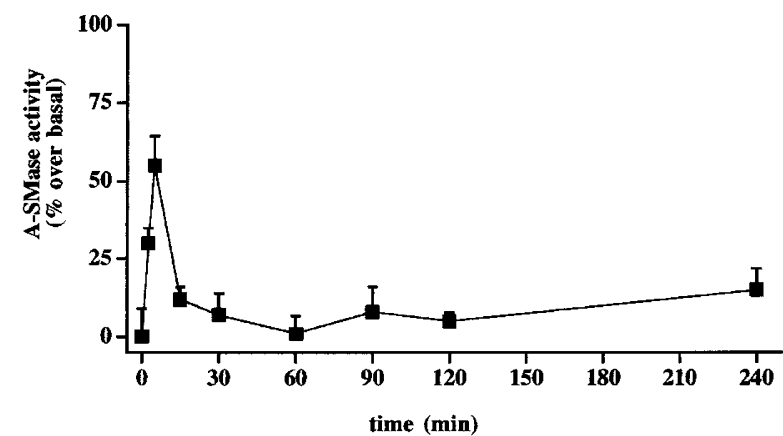

B

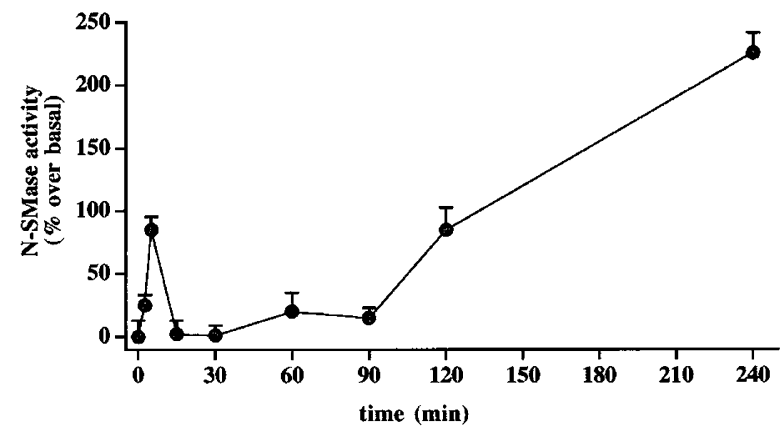

Figure 1 Kinetics of activation of A-SMase and N-SMase by TNF- $\alpha$ in U937 cells. Cells were treated with TNF- $\alpha(50 \mathrm{ng} / \mathrm{ml})$ and samples collected at the time points-indicated. A-SMase (A) and N-SMase (B) activities were determined in cell lysates by measuring sphingomyelin hydrolysis to phosphorylcholine at $\mathrm{pH} 5.5$ (for A-SMase activity) and 7.4 (for N-SMase activity). Values are expressed as $\% \pm$ S.E.M. over basal SMase activity $\left(1.28 \pm 0.6\right.$ and $0.52 \pm 0.3 \mathrm{nmol} / \mathrm{mg} \mathrm{h}^{-1}$ for A-SMase and N-SMase, respectively) $(n=5)$ either enzyme ( $\mathrm{pH} 5.5$ and 7.4 for A-SMase and N-SMase, respectively). As shown in Figure 1, activation by TNF- $\alpha$ of both A-SMase and $\mathrm{N}$-SMase was rapid in onset, as it was clearly detected after 2 min of treatment with the cytokine, peaked at $5 \mathrm{~min}$ and then diminished, returning to basal values after $30 \mathrm{~min}$. No further increase in A-SMase activity was detected during the observation period (4 h). However, there was a second prolonged phase of activation of $\mathrm{N}$ SMase, which commenced 90 min after TNF- $\alpha$ administration and continued increasing for the rest of the observation period (Figure 1B).

As we have shown previously in U937 cells, protection by $\mathrm{NO}$ from TNF- $\alpha$-induced apoptosis occurs in the first minutes after cytokine administration. ${ }^{6}$ We therefore investigated the effects of $\mathrm{NO}$ on the first phase of A-SMase and $\mathrm{N}$-SMase activity, measured at their peak (5 min after TNF $-\alpha$ ). Results obtained are shown in Figure 2A. Incubation of the cells with TNF- $\alpha$ in the presence of increasing concentrations of the NO donor S-nitrosoacetylpenicillamine (SNAP, $0-300 \mu \mathrm{M}$ ) resulted in inhibition of both SMase activities. This effect was dependent on the concentration of SNAP, with apparent $I_{50} S$ of $13.3 \pm 1.6$ and $40 \pm 3.8 \mu \mathrm{M} \quad(n=6)$ for A-SMase and $\mathrm{N}$ SMase, respectively.

A

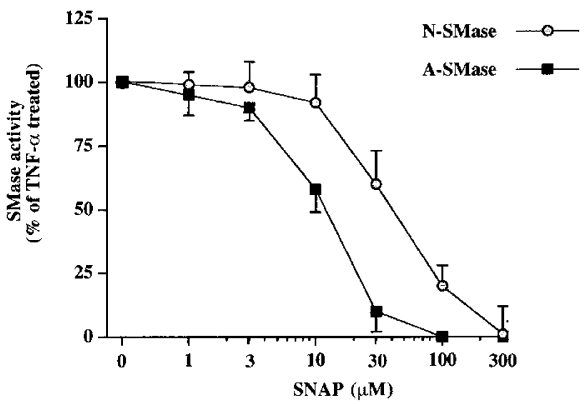

B

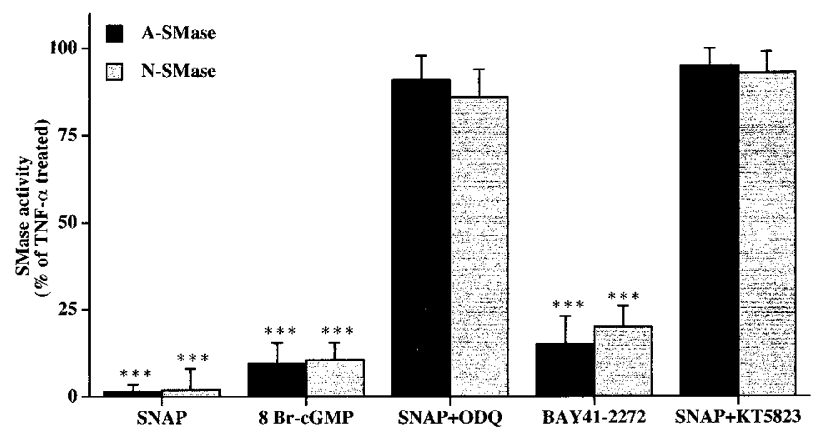

Figure 2 NO inhibits TNF- $\alpha$-triggered A-SMase and N-SMase activities through generation of CGMP and activation of protein kinase G. (A) U937 cells were treated for $5 \mathrm{~min}$ with TNF- $\alpha(50 \mathrm{ng} / \mathrm{ml})$ in the presence of increasing concentrations of the NO donor SNAP. (B) Cells were treated for $5 \mathrm{~min}$ with TNF- $\alpha$ with or without SNAP $(300 \mu \mathrm{M}), 8 \mathrm{Br}-\mathrm{cGMP}(1 \mathrm{mM}), \mathrm{SNAP}+\mathrm{ODQ}(1 \mu \mathrm{M})$, BAY $41-2272(1 \mu \mathrm{M})$ and SNAP+KT5823 $(1 \mu \mathrm{M})$. A-SMase and N-SMase activities were measured in $\mathbf{A}$ and $\mathbf{B}$ as described in the legend to Figure 1 and expressed as $\% \pm$ S.E.M. of those measured with TNF- $\alpha$ alone $(100 \%)$. Statistical values in the various samples are measured $v s$ cells treated with TNF- $\alpha$ alone $(n=6)$ 
We then analyzed the dependence of the inhibitory effect of NO on cGMP generation. To this end cells were exposed to TNF- $\alpha$ in the presence of either the cell membrane permeant cGMP analogue, 8 Br-cGMP (1 mM), or BAY $412272(1 \mu \mathrm{M})$, a compound that activates guanylate cyclase through an $\mathrm{NO}$-independent site. ${ }^{13}$ Under these conditions, activation of both A-SMase and $\mathrm{N}$-SMase by TNF- $\alpha$ was inhibited. Moreover, inhibition of guanylate cyclase with the specific inhibitor $H$-[1,2,4]oxadiazolo[4,3- $\alpha$ ]quinoxalin-1-one (ODQ) $(1 \mu \mathrm{M}),{ }^{14}$ reversed the inhibitory effect of SNAP $(300 \mu \mathrm{M})$ on both A-SMase and N-SMase activities (Figure 2B). The effect of SNAP was likewise inhibited by its co-incubation with KT5823 $(1 \mu \mathrm{M})$, an inhibitor of protein kinase $\mathrm{G}^{15}$ Basal sphingomyelin hydrolysis was not modified when SNAP, ODQ, BAY $412272,{ }^{8}$ Br-cGMP or KT5823 were administered without TNF- $\alpha$ (not shown). Taken together, these results indicate that NO inhibits TNF- $\alpha$-triggered A-SMase and $\mathrm{N}$ SMase activities via a mechanism involving activation of guanylate cyclase, formation of cGMP and activation of protein kinase $\mathrm{G}$.

The contribution of A-SMase and N-SMase to apoptosis stimulated by TNF- $\alpha$ has been widely studied and found to vary depending on the cell system. ${ }^{8,9,12,16,17}$ To our knowledge, however, there is no information on the specific contribution of each enzyme to the early signalling events leading to apoptosis. To elucidate this we used a range of inhibitors, namely imipramine, tricyclodecan-9-yl xanthate (D609) and monensin, which inhibit A-SMase activity, ${ }^{6,18,19}$ as well as scyphostatin and L-carnitine, which are inhibitors of N-SMase activity. ${ }^{20,21}$ When administered alone no drug had any effect on the basal level of sphingomyelin hydrolysis (not shown). At the concentrations used, however, imipramine $(20 \mu \mathrm{M})$, monensin $(1 \mu \mathrm{M})$ and D609 $(25 \mu \mathrm{g} / \mathrm{ml})$ were found to inhibit selectively TNF- $\alpha$-triggered A-SMase activity, while scyphostatin $(1 \mu \mathrm{M})$ and L-carnitine $(10 \mu \mathrm{g} / \mathrm{ml})$ appeared specific for the N-SMase activity (Figure 3A,B).

We used these compounds to evaluate the relative contribution of each SMase to the initial phases of apoptosis triggered by administration of TNF- $\alpha$ in the presence of the protein synthesis inhibitor cycloheximide $(\mathrm{CHX}, 1 \mu \mathrm{g} / \mathrm{ml}){ }^{6}$ Under these conditions, the kinetics of ASMase and N-SMase activation were indistinguishable from those observed with TNF- $\alpha$ alone (not shown). We analyzed several hallmarks of apoptosis, i.e. activation of the initiator caspase-8, measured $5 \mathrm{~min}$ after cytokine addition, DNA fragmentation, measured from 1 to $3 \mathrm{~h}$, and exposure of phosphatidylserine on the outer leaflet of the plasma membrane, measured at $3 \mathrm{~h}$. Basal activity of

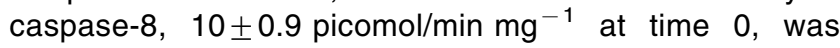
increased by $71 \pm 4.5 \%$ after $5 \mathrm{~min}$ of treatment with TNF$\alpha / \mathrm{CHX}(n=9)$. This increase was prevented by co-incubation with imipramine, D609, or monensin (Figure 4A). Consistently with this, A-SMase inhibitors prevented the reduction in the amount of uncleaved, inactive procaspase-8 observed after TNF- $\alpha / \mathrm{CHX}$ treatment (Figure 4B). Similarly, D609 and imipramine reduced TNF- $\alpha / \mathrm{CHX}$-induced DNAfragmentation and phosphatidylserine exposure (Figure 4C,D). By contrast, neither scyphostatin nor L-carnitine
A

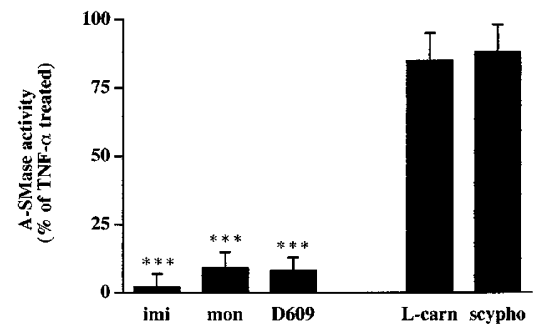

B

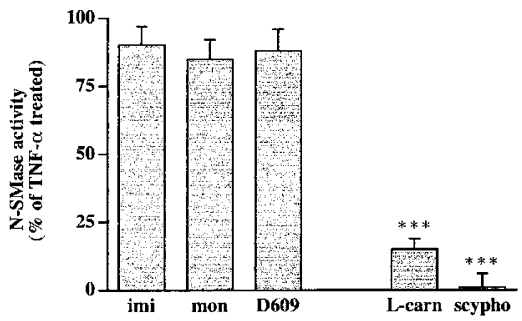

Figure 3 Specificity of action of imipramine, monensin, D609, L-carnitine and scyphostatin on TNF- $\alpha$-triggered A-SMase and N-SMase activities. U937 cells were treated for $5 \mathrm{~min}$ with TNF- $\alpha(50 \mathrm{ng} / \mathrm{ml})$ with or without either imipramine (imi, $20 \mu \mathrm{M})$, monensin (mon, $1 \mu \mathrm{M}), \mathrm{D} 609(25 \mu \mathrm{g} / \mathrm{ml})$, L-carnitine (L-carn, $10 \mu \mathrm{g} / \mathrm{ml}$ ) and scyphostatin (scypho, $1 \mu \mathrm{M}$ ). A-SMase (A) and N-SMase (B) activities were measured as described in the legend to Figure 1 and expressed as $\% \pm$ S.E.M. of those measured with TNF- $\alpha$ alone (100\%). Statistical values in the various samples are measured $v s$ cells treated with TNF- $\alpha$ alone $(n=5)$

had any appreciable effect on caspase-8 activation, DNA fragmentation and phosphatidylserine exposure (Figure $4 A-D)$. These results indicate that A-SMase contributes to early apoptotic signalling triggered by TNF- $\alpha$. In contrast, $\mathrm{N}$-SMase appears not to be involved at this stage of the process.

We then investigated whether the cGMP-dependent inhibition of A-SMase activity accounts for the NO/cGMP protection from TNF- $\alpha$-induced early apoptosis. To this end we examined the effects of the cyclic nucleotide directly. As shown in Figure 5, administration of $8 \mathrm{Br}$-cGMP inhibited both TNF- $\alpha / \mathrm{CHX}$-triggered caspase- 8 activation (at $5 \mathrm{~min}$ ) and DNA fragmentation ( $3 \mathrm{~h}$ time-point). When the cyclic nucleotide was administered together with imipramine, monensin or D609, neither caspase-8 activity nor DNA fragmentation were inhibited further. Administration of the long-chain natural ceramide analogue C16 ceramide $(30 \mu \mathrm{M})$ reversed the effects of $8 \mathrm{Br}$-cGMP and A-SMase inhibitors on both TNF- $\alpha / \mathrm{CHX}$-triggered caspase- 8 activation and DNA fragmentation. When administered alone, C16 ceramide had no effects on caspase-8 activation and DNA fragmentation in the period investigated (not shown, $n=5$ ). These results strongly suggest that the cGMPdependent, early inhibitory effect of NO on TNF- $\alpha$-induced apoptosis was due to the ability of NO to inhibit A-SMase activity and the ensuing generation of ceramide.

Finally, we investigated the role of this early mechanism of protection in the progress of the apoptotic process. Table 1 shows the kinetics of DNA fragmentation measured 3, 4.5 and $6 \mathrm{~h}$ after administration of TNF- $\alpha / \mathrm{CHX}$. Protection by 8 
$\mathbf{A}$

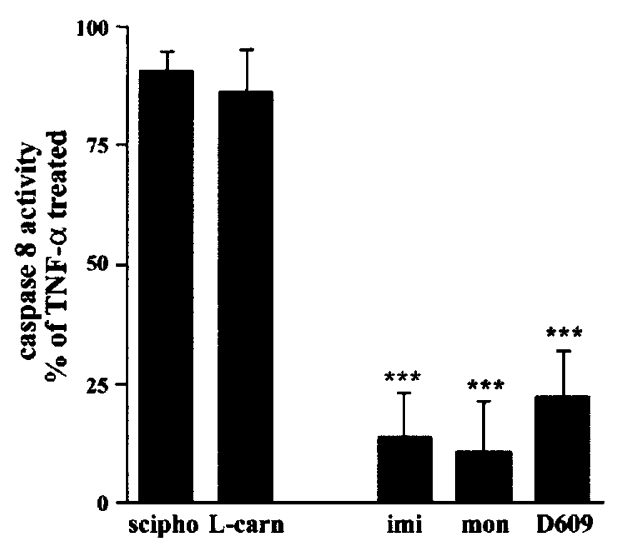

C

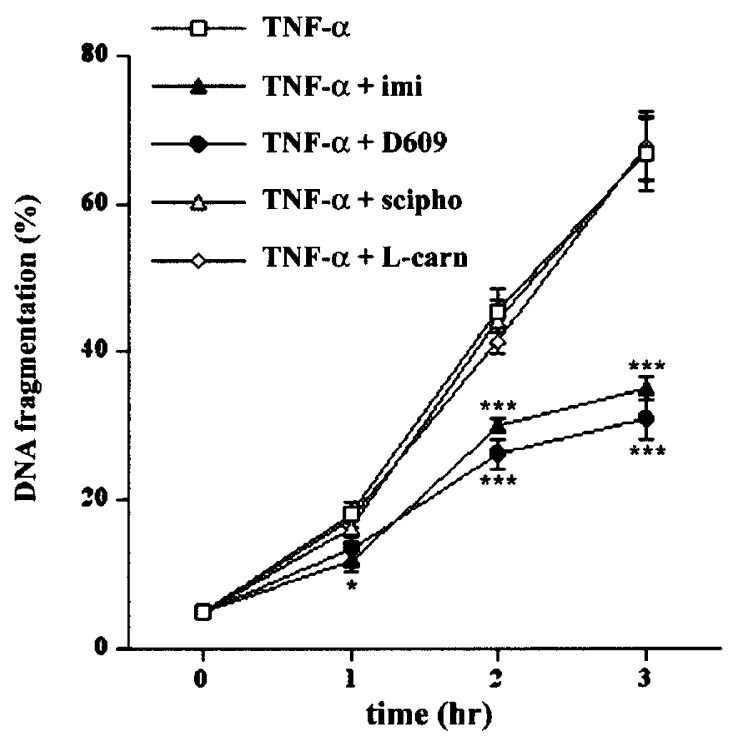

B

TNF $-\alpha-+\frac{\text { scipho }}{-+} \frac{\text { L-carn }}{-++} \frac{\text { D-609 }}{-+} \frac{\text { imi }}{-+}$

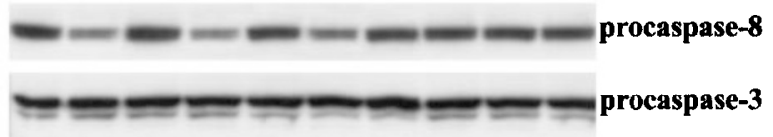

D phosphatidylserine exposure

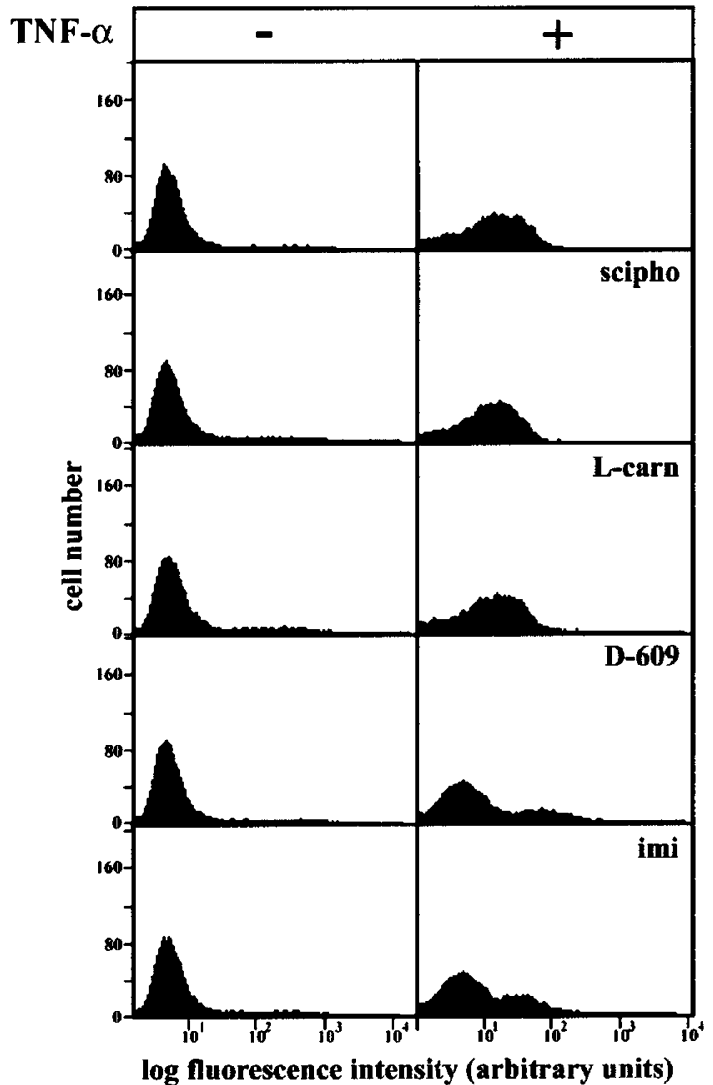

Figure 4 Involvement of A-SMase in caspase-8 activation, DNA fragmentation and phosphatidylserine exposure triggered by TNF- $\alpha / \mathrm{CHX}$. U937 cells were treated with TNF- $\alpha(50 \mathrm{ng} / \mathrm{ml}) / \mathrm{CHX}(1 \mu \mathrm{g} / \mathrm{ml})$ with or without imipramine (imi, $20 \mu \mathrm{M})$, monensin (mon, $1 \mu \mathrm{M})$, D609 (25 $\mu \mathrm{g} / \mathrm{ml}), \mathrm{L}-\mathrm{carnitine}(\mathrm{L}-\mathrm{carn}, 10 \mu \mathrm{g} / \mathrm{ml})$ or scyphostatin (scypho, $1 \mu \mathrm{M}$ ). Caspase-8 activity was measured after $5 \mathrm{~min}$, as both cleavage of its specific substrate $\mathrm{N}$-acetyl-IETD-7-amino-4trifluoromethylcoumarin (A), and proteolysis of the inactive zymogen, procaspase-8, detected by Western blotting (B). None of the treatment induced proteolysis of procaspase-3, an effector caspase activated during late stages of apoptosis, which was used as an internal control. DNA fragmentation (C) and phosphatidylserine exposure (D) were analyzed after $1-3 \mathrm{~h}$, and after $3 \mathrm{~h}$, respectively, of incubation with the cytokine, as detailed in the Materials and Methods section. Values in $\mathbf{A}$ are expressed as $\% \pm$ S.E.M. of those measured with TNF- $\alpha / \mathrm{CHX}$ alone (100\%). Statistical values in the various samples are measured vs cells treated with TNF- $\alpha / \mathrm{CHX}(n=6)$

Br-cGMP, D609 or imipramine was still significant at $4.5 \mathrm{~h}$, however, it was less than that measured at $3 \mathrm{~h}$. At the $6 \mathrm{~h}$ time-point, protection by these compounds was no longer observed, indicating that cGMP-dependent inhibition of ASMase delays, rather than prevents, TNF- $\alpha / \mathrm{CHX}$-induced apoptosis.

\section{Discussion}

The sphingolipid ceramide has recently been recognised as an important intracellular second messenger, contributing to regulation of various biological processes including inflammation, cell growth and differentiation. Often, however, the outcome of ceramide signalling is induction of cell death via apoptosis. ${ }^{7}$ Despite possible de novo formation of ceramide, in the vast majority of cells sphingomyelin appears to be the primary sphingolipid source for bioactive ceramide, thereby emphasising the critical role for SMases in initiating ceramideactivated apoptogenic signalling.

Two of these enzymes, A-SMase and N-SMase, have been shown to contribute substantially to apoptosis triggered by death receptors, although their contribution to 
A

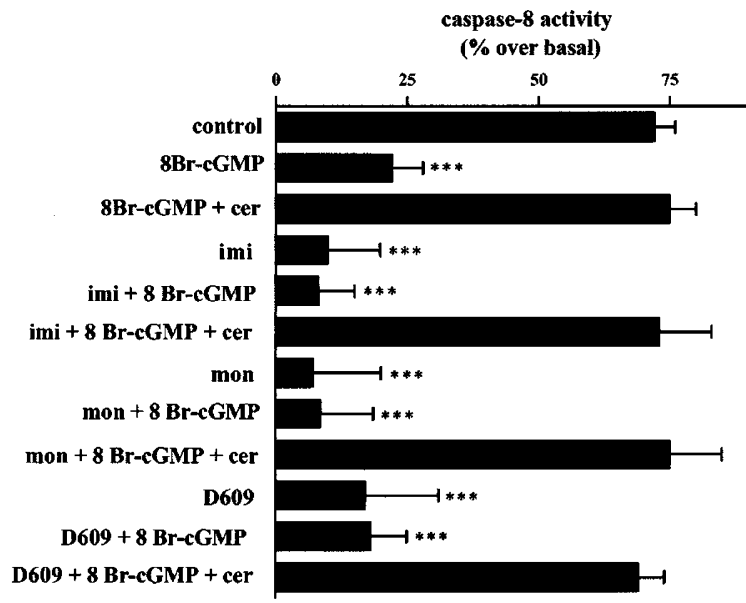

B

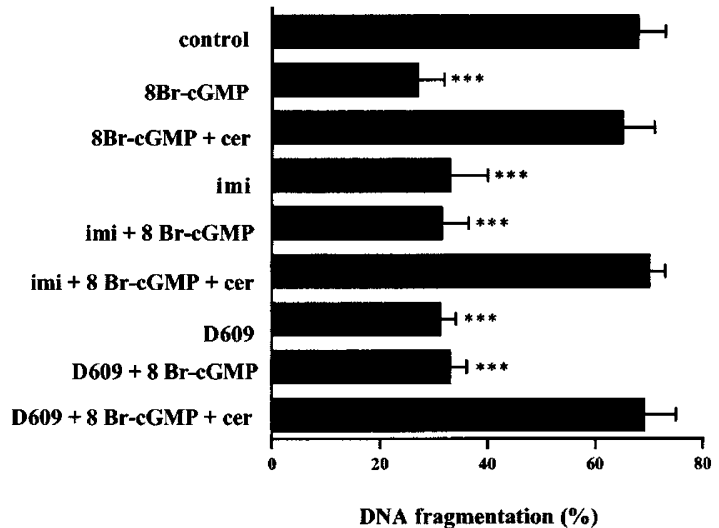

Figure 5 Inhibition of A-SMase by 8 Br-cGMP accounts for its ability to reduce TNF- $\alpha / \mathrm{CHX}$-triggered caspase-8 activation and DNA fragmentation. All the groups shown in the figure were treated with TNF- $\alpha(50 \mathrm{ng} / \mathrm{ml}) / \mathrm{CHX}(1 \mu \mathrm{g} /$ $\mathrm{ml}) .8 \mathrm{Br}-\mathrm{cGMP}(1 \mathrm{mM})$, imipramine (imi, $20 \mu \mathrm{M})$, monensin (mon, $1 \mu \mathrm{M})$, D609 $(25 \mu \mathrm{g} / \mathrm{ml})$, L-carnitine (L-carn, $10 \mu \mathrm{g} / \mathrm{ml})$, scyphostatin (scypho, $1 \mu \mathrm{M})$ and C16 ceramide (cer, $30 \mu \mathrm{M}$ ) were added in various combinations as detailed on the $y$ axis. Caspase-8 activity (A) was measured after $5 \mathrm{~min}$, DNA fragmentation (B) after $3 \mathrm{~h}$ of incubation with the cytokine, as detailed in the Materials and Methods section. Control in $\mathbf{A}$ and $\mathbf{B}$ represents caspase- 8 activity and DNA fragmentation, respectively, induced by TNF- $\alpha / \mathrm{CHX}$ alone $(n=5)$

apoptosis appears to vary depending on the tissues and cells investigated. ${ }^{8,9,16,17,22}$ The mechanisms of activation of SMases have been extensively studied. The enzymes are stimulated early after death receptor activation, downstream to recruitment to these receptors of proteins involved in initiating their apoptotic signalling, i.e. FAN (for N-SMase) and FADD (for A-SMase), ${ }^{17,23}$ with possible involvement of other early signals. ${ }^{22,24,25}$ Expression of dominant negative FAN and FADD gives rise to long-lasting inhibition of apoptosis, restored only by exogenous ceramide. $^{16,17}$

Knowledge about the regulatory mechanisms for SMases once they have been activated is still limited. Regulation of these enzymes by intracellular messengers, however, might be relevant to modulation of the whole apoptotic process, as already shown with other early
Table 1 Inhibition by cGMP and potentiation by A-SMase of TNF- $\alpha$-induced apoptosis are transient events

\begin{tabular}{lccc}
\hline & \multicolumn{3}{c}{ DNA fragmentation (\%) } \\
Time $(\mathbf{h})$ & $\mathbf{3}$ & $\mathbf{4 . 5}$ & $\mathbf{6}$ \\
\hline TNF- $\alpha$ & $65.2 \pm 5.1$ & $82.3 \pm 4.9$ & $94.3 \pm 4.2$ \\
TNF- $\alpha+8$ Br-cGMP & $27.0 \pm 2.1^{\star \star \star}$ & $59.5 \pm 3.3^{\star \star}$ & $88.1 \pm 4.8$ \\
TNF- $\alpha+$ imi & $33.0 \pm 5.3^{\star \star \star}$ & $62.1 \pm 4.1^{\star \star}$ & $95.6 \pm 6.1$ \\
TNF- $\alpha+$ D609 & $31.1 \pm 2.4^{\star \star \star}$ & $64.4 \pm 4.9^{\star}$ & $93.2 \pm 5.2$ \\
\hline
\end{tabular}

U937 cells were treated with TNF- $\alpha(50 \mathrm{ng} / \mathrm{ml}) / \mathrm{CHX}(1 \mu \mathrm{g} / \mathrm{ml})$ with or without 8 Br-cGMP $(1 \mathrm{mM})$, imipramine (imi, $20 \mu \mathrm{M})$ or D609 $(25 \mu \mathrm{g} / \mathrm{ml})$. DNA fragmentation was measured after $3,4.5$ and $6 \mathrm{~h}$ of incubation with the cytokine, as detailed in the Materials and Methods section. Values are expressed as $\% \pm$ S.E.M. Statistical values in the various samples are measured vs cells treated with TNF- $\alpha / \mathrm{CHX}(n=8)$

apoptotic events. ${ }^{1,2}$ We now suggest that NO might be one such regulatory messenger. In particular, NO was found to inhibit in a concentration-dependent manner the activation of both A-SMase and N-SMase triggered by TNF$\alpha$ in the first minutes after its administration to the cells. This action by NO was found to be mediated through stimulation of guanylate cyclase and to require activation of protein kinase $\mathrm{G}$. This latter may phosphorylate SMases directly or through intermediate proteins, as proposed for protein kinase $\mathrm{C}$ regulation of $\mathrm{N}$-SMase. ${ }^{26}$ The observation that NO regulates both SMases appears of particular relevance for sphingolipid metabolism, since $\mathrm{NO}$ is generated by a variety of stimuli in many physiological and pathological conditions. ${ }^{14}$

To evaluate the biological relevance of this NO/cGMP inhibition of SMases we investigated first the role of each enzyme in the early phases of apoptosis induced by TNF- $\alpha$ / $\mathrm{CHX}$, by measuring activation of the initiator caspase- 8 at $5 \mathrm{~min}$ and DNA fragmentation up to $3 \mathrm{~h}$. Our results, obtained using a range of structurally unrelated SMase inhibitors, demonstrate an involvement of A-SMase in early apoptosis triggered by TNF- $\alpha / \mathrm{CHX}$. This finding is in agreement with a previous report in these cells. ${ }^{12}$ Since, however, we found that TNF- $\alpha$ induced a second phase of $\mathrm{N}$-SMase (but not A-SMase) activation commencing about 90 min after cytokine administration, the later involvement of this enzyme in apoptosis cannot be excluded. ${ }^{17}$

We then analyzed the importance of NO/cGMP inhibition of A-SMase to the outcome of the apoptotic process. Inhibition of TNF- $\alpha / \mathrm{CHX}$-triggered caspase-8 activity and DNA fragmentation by the three A-SMase inhibitors used was mimicked by $8 \mathrm{Br}$-cGMP, but was not enhanced by coadministration of the cyclic nucleotide with the inhibitors. These results indicate that inhibition of A-SMase by $\mathrm{NO} /$ cGMP accounts for its protective effect. We found, however, that such a mechanism of protection operates only during early phases of apoptosis, since $8 \mathrm{Br}$-cGMP and A-SMase inhibitors lost their protective function progressively as apoptosis proceeded, becoming completely ineffective at later stages.

There are two implications of these observations. The first is that the contribution of A-SMase to the apoptotic process appears relevant only to its initial phases. Further studies are needed in order to establish whether this occurs 
only in the cell system we investigated or if it is a more general phenomenon. Such studies might also shed light on the discrepancies in the literature about involvement of A-SMase in apoptosis, ${ }^{8,9,16,17,22}$ which might be only apparent, and ultimately depend on, the time-window at which apoptosis is analyzed. The second implication is that the protective action on NO exerted through cGMP delays, rather then prevents apoptosis. This, together with the observation that cGMP acts through A-SMase inhibition, might be of importance in unravelling the overall mechanism responsible for the early, cGMP-dependent regulation of apoptosis. Location of A-SMase is still debated, despite evidence indicating that the enzyme involved in apoptosis is at the plasma membrane $;^{12,27-29}$ consistent reports, however, indicate mitochondria as a target for ceramide apoptogenic signalling. ${ }^{29-31}$ Interestingly, the targets described so far for the cGMP-dependent protective effect of $\mathrm{NO}$, namely the release of cytochrome $c$, the generation of reactive oxygen species and the collapse of the mitochondrial membrane potential, ${ }^{3-5}$ have all been linked to ceramide apoptogenic activity in mitochondria. ${ }^{29-31}$ An intriguing hypothesis is, therefore, that inhibition of SMase is the initial event in the cGMP-dependent protective action of $\mathrm{NO}$ in apoptosis. Such an action might synergise with another early protective action of NO, i.e. the cGMPindependent, direct inhibition of cytochrome $c$ oxidase in the mitochondrial respiratory chain which contributes to the maintenance of mitochondrial membrane potential during apoptosis. $^{32}$ In view of the fact that both guanylate cyclase and cytochrome $c$ oxidase are exquisitely sensitive to nanomolar concentrations of $\mathrm{NO}^{14,33}$ it is conceivable that $\mathrm{NO}$ is central to the fine-tuning of the mitochondria during the apoptotic process.

Although all the results we have now described have been obtained using exogenous $\mathrm{NO}$, it is likely that endogenously-generated NO will have the same effect. Indeed, in cells endowed with an endothelial NO synthase, TNF- $\alpha$ has been found to regulate its own apoptotic effect through generation of $\mathrm{NO}^{34}$ This generation of $\mathrm{NO}$ is stimulated by the cytokine in a ceramide-dependent way. ${ }^{34}$ Interestingly, other agents such as high-density lipoprotein, which do not induce apoptosis, have also been claimed to release NO via a ceramide-dependent process. ${ }^{35}$ This suggests that the reciprocal regulation between $\mathrm{NO}$ and ceramide might be relevant not only for apoptosis but for other, as yet not fully defined, biological endpoints. ${ }^{8}$

\section{Materials and Methods}

\section{Materials}

The following reagents were purchased as indicated: [N-methyl- ${ }^{14} \mathrm{C}$ ]sphingomyelin, $\left[{ }^{14} \mathrm{C}\right]$-thymidine and the Enhanced Chemiluminescence kit from Amersham Corporation (Little Chalfont, UK); recombinant human TNF- $\alpha$ and ODQ from Alexis Italia (Florence, Italy); N-acetyl-IETD-7-amino-4-trifluoromethylcoumarin from Eppendorf (Hamburg, Germany); Bay 41-2272 from Bayer AG (Wuppertal, Germany); D609 and SNAP from Calbiochem (Bad Soden, Germany); antibodies against the aminoterminal portions of procaspase- 8 and 3 from Santa Cruz Biotechnology (Santa Cruz, CA, USA); cell culture media from GIBCO (Basel, Switzerland) except for foetal clone III serum, obtained from Hyclone-Celbio, (Milan, Italy). Scyphostatin was a kind gift by Dr. T Ogita (Sankyo Ltd., Tokyo, Japan). Monensin, imipramine, C 16 ceramide and all the other chemicals were from Sigma (St.Louis, MO, USA).

\section{Cell culture and treatments}

U937 cells were routinely grown at $37^{\circ} \mathrm{C}, 5 \% \mathrm{CO}_{2}$, in RPMI 1640 supplemented with $10 \%$ heat-inactivated foetal clone III serum, $2 \mathrm{mM}$ glutamine, $100 \mathrm{U} / \mathrm{ml}$ streptomycin and $100 \mathrm{U} / \mathrm{ml}$ penicillin, and used within the tenth week from thawing. All the experiments were carried out in the above culture medium. Cell incubations with SNAP, ODQ, 8 $\mathrm{Br}$-cGMP, D609, L-carnitine, monensin, scyphostatin, or CHX were for $10 \mathrm{~min}$ prior to TNF- $\alpha$ administration. Imipramine was added $1 \mathrm{~h}$ before the experiments. SNAP was used at a concentration that does not produce cytotoxic effects in U937 cells, ${ }^{6}$ and D609 under conditions that do not stimulate ceramide generation. ${ }^{6}$

\section{Measurement of SMase activities}

Following pre-incubation with the various drug treatments, cell samples $\left(2 \times 10^{6}\right.$ cells $)$ were treated with TNF- $\alpha\left(50 \mathrm{ng} / \mathrm{ml}\right.$ at $\left.37^{\circ} \mathrm{C}\right)$ or TNF- $\alpha(50 \mathrm{ng} / \mathrm{ml})$ plus $\mathrm{CHX}(1 \mu \mathrm{g} / \mathrm{ml})$, and treatment was stopped by immersion of reaction tubes in a methanol/dry ice bath at the indicated time-points. Cells were then centrifuged $\left(1000 \mathrm{~g}\right.$ for $2 \mathrm{~min}$ at $\left.4^{\circ} \mathrm{C}\right)$ and the pellet washed once with ice-cold phosphate buffered saline. To assay A-SMase activity cell pellets were resuspended in $0.2 \mathrm{ml}$ of $0.1 \%$ Triton $\mathrm{X}-100$ at $4^{\circ} \mathrm{C}$ for $15 \mathrm{~min}$ and subsequently homogenised by repeated squeezing through an 18-gauge needle. Homogenates were then centrifuged ( $1000 \mathrm{~g}$ for $5 \mathrm{~min}$ at $4^{\circ} \mathrm{C}$ ) in order to remove nuclei and cellular debris and the supernatant was incubated for $2 \mathrm{~h}$ at $37^{\circ} \mathrm{C}$ in a buffer containing: $250 \mathrm{mM} \mathrm{Na}$ acetate, $1 \mathrm{mM}$ EDTA, [Nmethyl- ${ }^{14} \mathrm{C}$-sphingomyelin ( $55 \mathrm{mCi} / \mathrm{mmol} ; 50000$ d.p.m./assay), $\mathrm{pH}$ 5.5. To assay N-SMase activity, cell pellets were resuspended in $0.2 \mathrm{ml}$ of a buffer consisting of: $0.2 \%$ Triton X-100, $20 \mathrm{mM}$ HEPES, $1 \mathrm{mM} \mathrm{MgCl}$, $2 \mathrm{mM}$ EDTA, $5 \mathrm{mM}$ dithiothreitol, $0,1 \mathrm{mM} \mathrm{Na}_{3} \mathrm{VO}_{4}$, $30 \mathrm{mM}$ p-nitrophenylphosphate, $10 \mathrm{mM} \beta$-glycerophosphate, $750 \mu \mathrm{M}$ ATP, $1 \mathrm{mM}$ phenylmethylsulfonyl fluoride, $10 \mathrm{mM}$ leupeptin, $10 \mathrm{mM}$ pepstatin, $5 \mathrm{mg} / \mathrm{ml}$ soybean trypsin inhibitor and $2 \mathrm{mg} / \mathrm{ml}$ aprotinin, $\mathrm{pH}$ 7.4. After $5 \mathrm{~min}$ incubation on ice, cells were homogenised as above. Cell lysates were then incubated for $2 \mathrm{~h}$ at $37 \times \mathrm{C}$ in a buffer containing $20 \mathrm{mM}$ HEPES, $1 \mathrm{mM} \mathrm{MgCl} 2$ and $\left[\mathrm{N}\right.$-methyl- $\left.{ }^{14} \mathrm{C}\right]$-sphingomyelin ( $55 \mathrm{mCi} / \mathrm{mmol} ; 50000$ d.p.m./assay), $\mathrm{pH}$ 7.4. Reactions for both ASMase and N-SMase were stopped by addition of $250 \mu \mathrm{l}$ of ice-cold $\mathrm{CHCl} 3$ : $\mathrm{MeOH}\left(2: 1\right.$, vol: vol) and $250 \mu \mathrm{l}$ of ice-cold $\mathrm{H}_{2} \mathrm{O}$. Phosphorylcholine thus produced was separated from sphingomyelin by sequential washing with $800 \mu \mathrm{l}$ of ice-cold $\mathrm{CHCl}_{3}: \mathrm{MeOH}(2: 1$, vol:vol), $500 \mu \mathrm{l}$ of $\mathrm{CHCl}_{3}$ and $750 \mu \mathrm{l}$ of $\mathrm{CHCl}_{3}: \mathrm{MeOH}: \mathrm{H}_{2} \mathrm{O}$ $(2: 47: 48$, vol:vol:vol). Aqueous and organic phases were then collected separately and radioactive phosphorylcholine in the aqueous phase counted by liquid scintillation in a Beckman $\beta$-counter. Nonhydrolysed, radioactive sphingomyelin in the organic phase was routinely measured as an internal control. Samples containing either purified A-SMase or N-SMase (Sigma) were assayed in parallel as positive controls. Results were normalised to the protein content evaluated by the bicinchoninic acid procedure (BCA; Pierce, IL, USA).

\section{Measurement of caspase-8 activation}

Aliquots of $2 \times 10^{6}$ cells, pre-incubated with the various drug treatments described above, were treated for $5 \mathrm{~min}$ with TNF- $\alpha$ $(50 \mathrm{ng} / \mathrm{ml})$ in the presence of $\mathrm{CHX}(1 \mu \mathrm{g} / \mathrm{ml})$, washed in $150 \mathrm{mM} \mathrm{NaCl}$, 
$1 \mathrm{mM}$ EDTA, $2 \mathrm{mM} \mathrm{Na}_{2} \mathrm{P}_{2} \mathrm{O}_{6}, 30 \mathrm{mM} \mathrm{NaF}, 20 \mathrm{mM}$ HEPES, $\mathrm{pH} 7.5$ and lysed at the indicated time-points in the same buffer containing $1 \%$ Triton X-100, $0.1 \mathrm{mM}$ phenylmethylsulphonylfluoride, $10 \mu \mathrm{g} / \mathrm{ml}$ leupeptin and $10 \mathrm{mg} / \mathrm{ml}$ aprotinin. Soluble proteins $(100 \mu \mathrm{g})$ were diluted in a reaction buffer containing a final concentration of $25 \mathrm{mM}$ HEPES, $100 \mathrm{mM} \mathrm{NaCl}, 5 \mathrm{mM}$ dithiothreitol, $1 \mathrm{mM}$ EDTA, 0.1\% CHAPS and $10 \%$ sucrose. Caspase- 8 activity was assayed in a Perkin-EImer LS50 fluorometer, equipped with $400 \mathrm{~nm}$ excitation and $505 \mathrm{~nm}$ emission filters, by measuring for $1 \mathrm{~h}$ at $37^{\circ} \mathrm{C}$ the fluorescence emitted by the cleaved caspase-8 substrate, N-acetyl-IETD-7-amino-4-trifluoromethylcoumarin $(25 \mu \mathrm{M})$, calibrated with respect to a 7-amino-4trifluoromethylcoumarin concentration curve. Western blot analyses of procaspase-8 were carried out with $30 \mu \mathrm{g}$ of soluble proteins, separated on $12 \%$ SDS-PAGE and transferred onto nitro-cellulose membranes. Non-specific sites were blocked before immunolabelling by incubation for $1 \mathrm{~h}$ at room temperature with blotting buffer (PBS containing $0.1 \%$ Tween and $5 \%$ non-fat milk). The membranes were incubated overnight in blotting buffer with the anti-procaspase-8 antibody and washed five times for $1 \mathrm{~h}$ with blotting buffer. The secondary anti-mouse antibody was then added for $30 \mathrm{~min}$. After several washes of the membranes in blotting buffer, the antigens were revealed by Enhanced Chemiluminescence according to the manufacturer's instructions. As an internal control, all Western blots were subsequently stripped of the first antibody and reprobed with the antibody recognising procaspase-3. Stripping of the first antibody was carried out by incubating nitrocellulose filters for $30 \mathrm{~min}$ at $52^{\circ} \mathrm{C}$ with a buffer consisting of: $62.5 \mathrm{mM}$ Tris- $\mathrm{HCl}, 2 \%$ SDS, $1 \% \beta$-mercaptoethanol, $\mathrm{pH}$ 6.7. Filters were then washed twice for 10 min with $100 \mathrm{mM}$ Tris- $\mathrm{HCl}, 0.1 \%$ Tween $20, \mathrm{pH} 7.4$, before equilibration for $1 \mathrm{~h}$ in blotting buffer.

\section{Apoptosis detection}

Secondary DNA fragmentation was quantified using the filter binding assay as described. ${ }^{6}$ Briefly, the cells were labelled overnight with $\left[{ }^{14} \mathrm{C}\right]$-thymidine $(0.05 \mu \mathrm{Ci} / \mathrm{ml})$ and incubated for a further $6 \mathrm{~h}$ in a medium containing unlabelled thymidine $(1 \mu \mathrm{g} / \mathrm{ml})$ before incubation with or without the various compounds and treatment with TNF- $\alpha$ $(50 \mathrm{ng} / \mathrm{ml})$ plus $\mathrm{CHX}(1 \mu \mathrm{g} / \mathrm{ml})$. At the indicated time-points the cells were sedimented (1000 r.p.m., $5 \mathrm{~min}$ at $4^{\circ} \mathrm{C}$ ) and the pellet was resuspended in saline containing: $140 \mathrm{mM} \mathrm{NaCl}, 5 \mathrm{mM} \mathrm{KCl}, 5 \mathrm{mM}$ glucose, $5 \mathrm{mM}$ EDTA, $4 \mathrm{mM} \mathrm{Na} \mathrm{HCO}_{3}, \mathrm{pH}$ 8.3. Aliquots of $0.5 \times 10^{6}$ cells were then loaded onto protein adsorbing (polyvinylchloride) filters (25 mm, $2 \mu \mathrm{m}$ pore; Nuclepore, Pleasanton, CA, USA), washed with the same buffer and lysed with a solution containing $0.2 \%$ sarkosyl, $2 \mathrm{M} \mathrm{NaCl}$ and $40 \mathrm{mM}$ EDTA, $\mathrm{pH}$ 10.1. Filters were rinsed with EDTA (20 mM, pH 10.1) and then removed from the filter holders which were washed twice with $0.4 \mathrm{~N} \mathrm{NaOH}$. Radioactivity was counted in the lysates, EDTA washes, filters and filter holder washes.

Phosphatidylserine exposure at the external surface of the plasma membrane was detected by analysis of aliquots of $6 \times 10^{4}$ cells, stained for $15 \mathrm{~min}$ with FITC-labelled annexin V $(1 \mu \mathrm{g} / \mathrm{ml})$, using a Fluorescence-Activated Cell Sorter (FACStar Plus, Becton Dickinson, Sunnyvale, CA, USA) as described previously. ${ }^{10}$

\section{Statistical analysis}

The results are expressed as means \pm standard error of the mean (S.E.M.); $n$ represents the number of individual experiments. Statistical analysis was carried out using the Student's $t$-test for unpaired variables (two-tailed). The asterisks ${ }^{*},{ }^{* *}$ and ${ }^{* * *}$ in the figure panels and in Table 1 refer to statistical probabilities $(P)$ of $<0.5,<0.01$ and $<0.001$, respectively, measured for the cells treated in the various experimental conditions $v s$ the cells treated with TNF- $\alpha$ alone (Figures $1-3$ ) or TNF- $\alpha$ and $\mathrm{CHX}$ (Figure 4 and Table 1).

\section{Acknowledgements}

We thank Annie Higgs and Jacopo Meldolesi for their critical revision of the manuscript, and Céline De Nadai for her help in the initial phases of the project. This work was supported by grants from: Italian Association for Cancer Research (E Clementi); Consiglio Nazionale delle Ricerche, Target Project Biotechnology and Agenzia 2000 (E Clementi); cofinanziamento 2001 from the Ministero dell'Istruzione, dell'Università e della Ricerca (E Clementi and Jacopo Meldolesi).

\section{References}

1. Zimmermann KC, Bonzen C and Reed DR (2001) The machinery of programmed cell death. Pharmacol. Ther. 92: 57-70

2. Borner C, Monney L, Olivier R, Rosse T, Hacki J and Conus S (1999) Life and death in a medieval atmosphere. Cell Death Differ. 6: 201-206

3. Liu L and Stamler JS (1999) NO: an inhibitor of cell death. Cell Death Differ. 6: 937-942

4. Takuma K, Phuagphong P, Lee E, Mori K, Baba A and Matsuda T (2001) Antiapoptotic effect of cGMP in cultured astrocytes: inhibition by cGMP-dependent protein kinase of mitochondrial permeable transition pore. J. Biol. Chem. 276: 48093-48099

5. Zamora R, Alarcon L, Vodovotz Y, Betten B, Kim PK, Gibson KF and Billiar TR (2001) Nitric oxide suppresses the expression of Bcl-2 binding protein BNIP3 in hepatocytes. J. Biol. Chem. 276: 46887-46895

6. De Nadai C, Sestili P, Cantoni O, Liévremont JP, Sciorati C, Barsacchi R, Moncada S, Meldolesi J and Clementi E (2000) Nitric oxide inhibits tumor necrosis factor- $\alpha$-induced apoptosis by reducing the generation of ceramide. Proc. Natl. Acad. Sci. USA. 97: 5480-5485

7. Kolesnick, RN and Krönke M (1998) Regulation of ceramide production and apoptosis. Annu. Rev. Physiol. 60: 643-665

8. Perry DK and Hannun YA (1998) The role of ceramide in cell signaling. Biochim. Biophys. Acta 1436: 233-243

9. Levade Tand Jaffrézou J-P (1999) Signalling sphingomyelinases: which, where, how and why? Biophys. Acta 1438: 1-17

10. Sciorati C, Rovere P, Ferrarini M, Heltai S, Manfredi AA and Clementi E (1997) Autocrine nitric oxide modulates CD95-induced apoptosis in $\gamma \delta$ Tlymphocytes. J. Biol. Chem. 272: 23211-23215

11. Sciorati $C$, Rovere P, Ferrarini M, Paolucci $C$, Heltai S, Vaiani R, Clementi $E$ and Manfredi AA (1999) Generation of nitric oxide by the inducible nitric oxide synthase protects $\gamma \delta$ T cells from Mycobacterium tuberculosis-induced apoptosis. J. Immunol. 163: 1570-1576

12. Schütze S, Machleidt T, Adam D, Schwandner R, Wiegmann K, Kruse ML, Heinrich M, Wickel M and Krönke M (1999) Inhibition of receptor internalization by monodansylcadaverine selectively blocks $p 55$ tumor necrosis factor receptor death domain signaling. J. Biol. Chem. 274: 10203-10212

13. Stasch JP, Becker EM, Alonso-Alija C, Apeler H, Dembowsky K, Feurer A, Gerzer R, Minuth T, Perzborn E, Pleiss U, Schroder H, Schroeder W, Stahl E, Steinke W, Straub A and Schramm M (2001) NO-independent regulatory site on soluble guanylate cyclase. Nature 410:212-215

14. Moncada $S$ and Higgs EA (1995) Molecular mechanisms and therapeutic strategies related to nitric oxide. FASEB J. 9: $1319-1330$

15. Gadbois DM, Crissman HA, Tobey RA and Bradbury EM (1992) Multiple kinase arrest points in the G1 phase of nontransformed mammalian cells are absent in transformed cells. Proc. Natl. Acad. Sci. USA. 89: 8626-8630

16. Lozano J, Menendez S, Morales A, Ehleiter D, Liao WC, Wagman R, HaimovitzFriedman A, Fuks Z and Kolesnick R (2001) Cell autonomous apoptosis defects in acid sphingomyelinase knockout fibroblasts. J. Biol. Chem. 276: 442-448

17. Ségui B, CuvillierO, Adam-Klages S, Garcia V, Malagarie-CazenaveS, Lévéque S, Caspar-Bauguil S, Coudert J, Salvayre R, Krönke M and Levade T (2001) Involvement of FAN in TNF-induced apoptosis. J. Clin. Invest. 108: 143-151 
18. Jensen JM, Schütze S, Forl M, Krönke M and Proksch E (1999) Roles for tumor necrosis factor receptor p55 and sphingomyelinase in repairing the cutaneous permeability barrier. J. Clin. Invest. 104: 1761-1770

19. Garcia-Ruiz C, Mari M, Morales A, Colell A, Ardite E and Fernandez-Checa JC (2000) Human placenta sphingomyelinase, an exogenous acidic pH-optimum sphingomyelinase, induces oxidative stress, glutathione depletion, and apoptosis in rat hepatocytes. Hepatol. 32: 56-65

20. Tanaka M, Nara, F, Suzuki-Konagai K, Hosoya T and Ogita T (1997) Structural elucidation of scyphostatin, an inhibitor of membrane-bound neutral sphingomyelinase. J. Am. Chem. Soc. 116: 7871-7872

21. Andrieu-AbadieN, Jaffrézou JP, Hatem S, Laurent G, Levade T and MercaiderJJ (1999) L-carnitine prevents doxorubicin-induced apoptosis of cardiac myocytes: role of inhibition of ceramide generation. FASEB J. 13: 1501-1510

22. Brenner B, Ferlinz K, Grassmé H, Weller M, Koppenhoefer U, Dichgans J, Sandhoff K, Lang F and Gulbins E (1998) Fas/CD95/Apo-l activates the acidic sphingomyelinase via caspases. Cell Death Differ. 5: 29-37

23. Schwandner R, Wiegmann K, Bernardo K, Kreder D and Krönke M (1998) TNF receptor death domain-associated proteins TRADD and FADD signal activation of acid sphingomyelinase. J. Biol. Chem. 273: 5916-5922

24. Dbaibo GS, Perry DK, Gamard CJ, PlattR, Poirier GG, Obeid LM and Hannun YA (1997) Cytokine response modifier A (CrmA) inhibits ceramide formation in response to tumor necrosis factor (TNF)- $\alpha$ : CrmA and Bcl-2 target distinct components in the apoptotic pathway. J. Exp. Med. 85: 481-490

25. Jayadev S, Hayter HL, Andrieu N, Gamard CJ, Liu B, Balu R, Hayakawa M, Ito F and Hannun Y (1997) Phospholipase A2 is necessary for tumor necrosis factor $\alpha$ induced ceramide generation in L929 cells. J. Biol. Chem. 272: 17196-17203

26. Mansat V, Laurent G, Levade T, Bettaieb A and Jaffrézou JP (1997) The protein kinase $C$ activators phorbol esters and phosphatidylserine inhibit neutral sphingomyelinase activation, ceramide generation, and apoptosis triggered by daunorubicin. Cancer Res. 57: 5300-5304
27. Ségui B, Bezombes C, Uro-Coste E, Medin JA, Andrieu-Abadie N, Auge N, Brouchet A, Laurent G, Salvayre R, Jaffrézou JP and Levade T (2000) Stressinduced apoptosis is not mediated by endolysosomal ceramide. FASEB J. 14: $36-47$

28. Grassmé H, Jekle A, Riehle A, Schwarz H, BergerJ, SandhoffK, Kolesnick Rand Gulbins E (2001) CD95 signaling via ceramide-rich membrane rafts. J. Biol. Chem. 276: 20589-20596

29. Birbes H, El Bawab S, Hannun YA and Obeid LM (2001) Selective hydrolysis of a mitochondrial pool of sphingomyelin induces apoptosis. FASEB J. 15: 2669 2679

30. Garcia-Ruiz C, Colell A, Mari M, Morales A and Fernandez-Checa JC (1997) Direct effect of ceramide on the mitochondrial electron transport chain leads to generation of reactive oxygen species. Role of mitochondrial glutathione. J. Biol. Chem. 272: 11369-11377

31. Ghafourifar P, Klein SD, Schucht O, SchenkU, Pruschy M, Rocha S and Richter C. (1999) Ceramide induces cytochrome c release from isolated mitochondria Importance of mitochondrial redox state. J. Biol. Chem. 274:6080-6088

32. Beltràn B, Mathur A, Duchen MR, Erusalimsky JD and Moncada S (2000) The effect of nitric oxide on cell respiration: A key to understanding its role in cell survival or death. Proc. Natl. Acad. Sci. USA. 97: 14602-14607

33. Brown GC (1999) Nitric oxide and mitochondrial respiration. Biochim. Biophys. Acta 1411: 351-369

34 Bulotta S, Barsacchi R, Rotiroti D, Borgese N and Clementi E (2001) Activation of the endothelial nitric-oxide synthase by tumor necrosis factor- $\alpha$. A novel feedback mechanism regulating cell death. J. Biol. Chem. 276: 6529-6536

35. Li XA, Titlow WB, Jackson BA, Giltiay N, Nikolova-Karakashian M, Uittenbogaard A and Smart EJ (2002) High-density lipoprotein binding to scavenger receptor class $B$, type I activates endothelial nitric oxide synthase in a ceramide-dependent manner. J. Biol. Chem. 277: 11058-11063 